\title{
REPRESENTASI SISWA VISUAL, AUDITORI DAN KINESTETIK DALAM MENYELESAIKAN MASALAH MATEMATIKA
}

\author{
Akhmad Faisal Hidayat ${ }^{1}$ \\ Universitas Batanghari Jambi ${ }^{1}$ \\ e-mail: akhmad.faisal.hidayat@unbari.ac.id
}

\begin{abstract}
ABSTRAK
Kemampuan representasi dan kemampuan pemecahan masalah merupakan dua diantara kemampuan matematis yang penting untuk dikembangkan. Memecahkan masalah membutuhkan kemampuan untuk me-recall informasi-informasi yang dibutuhkan serta direpresentasikan baik secara visual maupun verbal. Informasi-informasi tersebut diperoleh, dikelola dan di-recall melalui sebuah sistem yang disebut sebagai gaya belajar. Penelitian ini melibatkan siswa yang mengikuti pembinaan olimpiade matematika tingkat sekolah dengan tujuan untuk memperoleh deskripsi mengenai representasi siswa dalam memecahkan masalah matematika. Subjek dipilih menggunakan teknik purposive sampling berdasarkan gaya belajar visual, auditori dan kinestetik. Hasil penelitian menunjukkan subjek bergaya belajar visual dan auditori, keduanya menunjukkan tiga indikator representasi matematis dalam memecahkan masalah terkait materi bilangan, permutasi, kombinasi dan geometri. Sedangkan subjek bergaya belajar kinestetik hanya menunjukkan dua indikator representasi matematis, yakni representasi visual dan representasi verbal menggunakan kata-kata atau teks tertulis. Pada tahap penyajian data, ketiga subjek melakukannya dengan membuat gambar geometri dan model matematika berdasarkan situasi yang diberikan. Namun gambar dan model yang dibuat oleh subjek kinestetik pada soal geometri kurang tepat sehingga kurang membantu dalam menggambarkan situasi permasalahan yang sebenarnya. Sedangkan pada tahap penyelesaian masalah, ketiga subjek melakukannya dengan menggunakan pola dan menarik kesimpulan dari pola yang dibuat sebagai solusi penyelesaian. Selain itu subjek auditori juga menggunakan ekspresi matematika dalam penyelesaian masalah geometri.
\end{abstract}

Kata kunci : Visual; Auditori; Kinestetik; Masalah Matematika; Representasi

\begin{abstract}
Representative skills and problem solving abilities are two of the mathematical abilities that are important to develop. Solving problems requires the ability to recall the information needed and represented both visually and verbally. The information is obtained, managed and recalled through a system known as learning styles. This study involved students who participated in the coaching of the school level mathematics olympiad with the aim of obtaining a description of the student's representation in solving mathematics problems. Subjects were selected using purposive sampling technique based on visual, auditory and kinesthetic learning styles. The results showed that the subjects had visual and auditory learning styles, both of which showed three indicators of mathematical representation in solving problems related to numbers, permutations, combinations and geometry. Meanwhile, the kinesthetic learning style subject only shows two indicators of mathematical representation, namely visual representations and verbal representations using words or written text. At the data presentation stage, the three subjects did this by making geometric drawings and mathematical models based on the given situation. However, the images and models made by the kinesthetic subject on geometry problems are less precise so they are less helpful in describing the real problem situation. Meanwhile, at the problem solving stage, the three subjects did it by using a pattern and drawing conclusions from the pattern made as a solution. In addition, auditory subjects also use mathematical expressions in solving geometric problems.
\end{abstract}

Keywords : Visual; Auditory; Kinesthetic; Mathematics Problem; Representation Ability

\section{PENDAHULUAN}

Tujuan pembelajaran matematika sebagaimana yang tertuang dalam standar kompetensi mata pelajaran matematika ialah:
1) Melatih cara berpikir dan bernalar dalam menarik kesimpulan; 2) Mengembangkan aktifitas kreatif yang melibatkan imajinasi, intuisi dan penemuan; 3) Mengembangkan 
kemampuan pemecahan masalah; 4) Mengembangkan kemampuan menyampaikan informasi atau mengkomunikasikan gagasan (representasi), antara lain melalui pembicaraan lisan, grafik, peta dan diagram (Ekawati, 2011). Selain itu, menurut National Counsil of Teachers of Mathematics (NCTM, 2000) terdapat lima standar kemampuan matematis yang harus dimiliki oleh siswa, yakni: 1) Kemampuan penalaran (reasoning); 2) Kemampuan komunikasi (communication); 3) Kemampuan koneksi (connection); 4) Kemampuan pemecahan masalah (problem solving); 5) Kemampuan representasi (representation). Berdasarkan uraian tersebut, maka kemampuan pemecahan masalah dan kemampuan representasi merupakan dua diantara kemampuan matematis yang perlu dikembangkan dan harus dimiliki oleh siswa.

Menurut Van De Walle (dalam Danoebroto, 2011) salah satu aspek dalam diri siswa yang perlu dikembangkan untuk menunjang kemampuan pemecahan masalah ialah penggunaan strategi pemecahan masalah. Selanjutnya Resnick dan Ford (dalam Danoebroto, 2011) mengemukakan tiga aspek yang mempengaruhi kemampuan siswa dalam merancang strategi pemecahan masalah, yakni: 1) Struktur pengetahuan siswa; 2) Keterampilan dalam memahami ruang lingkup masalah; 3) Keterampilan dalam merepresentasikan masalah. Dengan demikian representasi berpengaruh terhadap cara siswa dalam memecahkan masalah. Selain itu, representasi seseorang sangat bergantung pada bagaimana cara dia memperoleh dan mengolah informasi.

Pemerolehan dan pengolahan informasi yang terjadi dalam diri seseorang memiliki peran penting terhadap kualitas informasi yang tersimpan di dalam memorinya. Sedangkan kualitas memori tentunya juga berpengaruh dalam proses merecall informasi-informasi yang sudah ada untuk digunakan kembali ketika dibutuhkan, terutama dalam hal memecahkan masalah. Struktur informasi yang tersimpan di dalam kognisi seseorang dapat tergambarkan melalui respon yang ia berikan dalam bentuk bahasa visual maupun verbal ketika ia dihadapkan pada suatu masalah. Semakin baik struktur bahasa yang disampaikan, maka semakin baik pula struktur kognisinya. Sehingga akan memudahkan ia dalam memecahkan suatu permasalahan. Felder dan Henriques (1995) mengemukakan bahwa cara seseorang dalam memperoleh, mempertahankan dan mendapatkan kembali sebuah informasi disebut sebagai gaya belajar. Hasrul (2009) menyatakan bahwa gaya belajar merupakan suatu kombinasi dari bagaimana seseorang menyerap dan kemudian mengatur serta mengolah kembali informasi tersebut (recall). Dengan demikian, dapat dikatakan bahwa gaya belajar merupakan cara bagaimana seseorang menyerap dan mengolah informasi, belajar serta mengkomunikasikannya kembali sehingga menjadi sesuatu yang mudah dan indah, sehingga erat kaitannya dengan representasi.

\section{Representasi}

Sejumlah pakar (Goldin, Ostad, Hiebert \& Carpenter dalam Kartini, 2009: 365) membagi representasi menjadi dua bagian, yakni reperesentasi internal dan eksternal. Representasi internal terkait dengan bagaimana seseorang berpikir mengenai suatu ide/gagasan matematika. Oleh karena itu representasi internal seseorang tidak bisa secara langsung diamati karena merupakan aktifitas mental yang berlangsung di dalam pikirannya. Namun demikian, aktifitas mental tersebut memiliki kaitan yang erat dengan ungkapan-ungkapan yang ditampilkan seseorang dalam bentuk gambar (visual), kata-kata (verbal) atau simbol matematika yang dapat diamati secara fisik. Ungkapan-ungkapan tersebut lebih dikenal sebagai representasi eksternal.

Beberapa definisi yang dikemukakan para ahli terkait dengan representasi antara lain:

a. Representasi merupakan cara/ungkapan yang digunakan seseorang dalam mengkomunikasikan jawaban atau gagasan (Cai, Lane \& Jacabcsin, 1996: 243).

b. Representasi adalah konfigurasi, bentuk atau susunan yang dapat menggambarkan, 
mewakili atau melambangkan sesuatu dalam suatu cara tertentu (Goldin, 1996: 400).

c. Representasi ialah model atau bentuk pengganti dari suatu situasi masalah dalam menemukan solusi yang dituangkan dalam bentuk gambar, kata-kata atau simbol matematika (Hwang, Chen, Dung, Yang 2007: 192)

Berdasarkan beberapa definisi di atas, apabila representasi dikaitkan dengan matematika, maka dapat disimpulkan bahwa representasi adalah bentuk konkrit dari ide abstrak matematika yang dituangkan dalam bentuk gambar (visual), kata-kata (verbal) atau simbol matematika sehingga mudah dipahami.

Lebih rinci lagi Mudzakkir dalam penelitiannya mengelompokkan representasi matematis ke dalam tiga bentuk, yaitu 1) Representasi visual berupa diagram, grafik, atau tabel, dan gambar; 2) Persamaan atau ekspresi matematika; dan 3) Kata-kata atau teks tertulis.

Adapun indikatornya adalah sebagai berikut:

Tabel 1. Indikator Representasi

\begin{tabular}{|c|c|c|}
\hline No & Representasi & Bentuk Operasional \\
\hline 1. & $\begin{array}{l}\text { Representasi visual } \\
\text { a) Diagram, tabel } \\
\text { dan grafik } \\
\text { b) Gambar }\end{array}$ & $\begin{array}{l}\text { - Menyajikan kembali data atau informasi dari suatu representasi diagram, } \\
\text { tabel atau grafik. } \\
\text { - Menggunakan ekspresi visual untukmenyelesaikan masalah } \\
\text { - Membuat gambar pola-pola geometri } \\
\text { - Membuat gambar untuk memperjelas masalah dan memfasilitasi } \\
\text { penyelesaiannya }\end{array}$ \\
\hline 2. & $\begin{array}{l}\text { Persamaan atau } \\
\text { ekspresi } \\
\text { matematika }\end{array}$ & $\begin{array}{l}\text { - Membuat persamaan atau model matematika dari representasi lain yang } \\
\text { diberikan. } \\
\text { - Membuat konjektur dari suatu pola bilangan. } \\
\text { - Menyelesaikan masalah dengan melibatkan ekspresi matematis. }\end{array}$ \\
\hline 3. & $\begin{array}{l}\text { Kata-kata atau teks } \\
\text { tertulis }\end{array}$ & $\begin{array}{l}\text { - Membuat situasi masalah berdasarkan data atau representasi yang } \\
\text { diberikan. } \\
\text { - Menuliskan interpretasi atau suatu representasi. } \\
\text { - Menuliskan langkah-langkah penyelesaian masalah matematika dengan } \\
\text { kata-kata. }\end{array}$ \\
\hline
\end{tabular}

Indikator-indikator representasi matematika informasi dan penyelesaian masalah. Secara yang akan digunakan dalam penelitian ini rinci diuraikan dalam tabel berikut. terbagi menjadi dua bagian yaitu penyajian

Tabel 2. Indikator Representasi Siswa dalam Memecahkan Masalah Matematika

\begin{tabular}{|c|c|c|c|}
\hline No & Representasi & Bentuk Operasional & Ket \\
\hline 1. & $\begin{array}{l}\text { Representasi } \\
\text { visual }\end{array}$ & $\begin{array}{ll}- & \text { Membuat gambar pola-pola geometri } \\
\text { - } & \text { Membuat gambar untuk memperjelas masalah dan } \\
& \text { memfasilitasi penyelesaiannya }\end{array}$ & $\begin{array}{ll} & \text { Penyajian informasi } \\
\text { - } & \text { Penyajian informasi }\end{array}$ \\
\hline 2. & $\begin{array}{l}\text { Persamaan } \\
\text { atau ekspresi } \\
\text { matematika }\end{array}$ & $\begin{array}{l}\text { - Membuat model matematika dari masalah yang } \\
\text { diberikan. } \\
\text { - Membuat pola dalam menyelesaikan masalah yang } \\
\text { diberikan. } \\
\text { - Menyelesaikan masalah dengan melibatkan ekspresi } \\
\text { matematis. }\end{array}$ & $\begin{array}{ll}\text { - } & \text { Penyajian informasi } \\
\text { - } & \text { Penyelesaian masalah } \\
\text { - } & \text { Penyelesaian masalah }\end{array}$ \\
\hline 3. & $\begin{array}{l}\text { Kata-kata atau } \\
\text { teks } \\
\text { tertulis }\end{array}$ & $\begin{array}{l}\text { - Membuat situasi masalah berdasarkan masalah yang } \\
\text { diberikan. } \\
\text { - Menuliskan langkah-langkah penyelesaian masalah } \\
\text { dengan kata-kata. } \\
\text { - Membuat kesimpulan dari suatu pola. } \\
\text { - Menuliskan interpretasi dari suatu representasi. }\end{array}$ & $\begin{array}{ll}\text { - } & \text { Penyajian informasi } \\
\text { - } & \text { Penyelesaian masalah } \\
\text { - } & \text { Penyelesaian masalah } \\
\text { - } & \text { Penyelesaian masalah }\end{array}$ \\
\hline
\end{tabular}




\section{$\pi$ (Phi)}

Masalah Matematika

Masalah merupakan kesenjangan/gap yang terjadi antara harapan dengan kenyataan. Krulik dan Rudnick (Sitanggang, 2017) mendefinisikan masalah sebagai suatu situasi yang dihadapi oleh seseorang atau kelompok yang memerlukan jalan keluar, namun tidak memiliki cara langsung menuju solusi tersebut. Terkait dengan matematika, Hudoyo (1988) mengemukakan dua syarat sehingga pertanyaan dapat menjadi masalah, yakni pertanyaan tersebut dapat dimengerti, namun memuat tantangan dalam menjawabnya serta pertanyaan tersebut tidak dapat dijawab melalui prosedur rutin. Polya (1973) membagi masalah menjadi dua, yakni masalah dalam menemukan (problem to find) dan masalah dalam membuktikan (problem to prove).

Masalah dalam matematika umumnya berupa soal-soal matematika. Hudoyo (1997) membagi beberapa jenis masalah matematis, yakni: a) Masalah translasi, merupakan masalah kehidupan sehari-hari yang untuk menyelesaikannya perlu translasi dari bentuk verbal ke bentuk model matematika. b) Masalah aplikasi, mengarahkan siswa untuk menggunakan berbagai macam keterampilan dan prosedur rutin matematika dalam menyelesaikannya. c) Masalah proses, digunakan untuk melatih siswa dalam menyusun langkah-langkah serta merumuskan pola dan strategi khusus dalam menyelesaikan masalah. Masalah seperti ini dapat melatih keterampilan siswa dalam menyelesaikan masalah sehingga terbiasa menggunakan strategi tertentu. d) Masalah teka-teki, seringkali digunakan sebagai media rekreasi dan refresing, agar pembelajaran matematika dapat berlangsung dengan efektif dan menyenangkan.

Masalah yang dimaksud oleh Hudoyo dapat berupa soal matematika non-rutin ataupun soal-soal yang berkaitan dengan

konteks kehidupan disekitar siswa (kontekstual), sehingga mereka merasa tertantang untuk menyelesaikannya. Oleh karena itu, masalah matematika yang dimaksud dalam penelitian ini ialah soal-soal matematika yang kontekstual, sehingga siswa menjadi tertantang untuk menyelesaikannya atau menemukan solusinya.

\section{Memecahkan Masalah Matematika}

Memecahan masalah merupakan serangkaian kegiatan yang dilakukan seseorang dalam rangka menemukan solusi yang tepat dari masalah tersebut. Dalam memecahkan masalah, setiap orang mungkin memilih strategi yang berbeda. Menurut Arifin (2010: 111) secara terperinci, strategi pemecahan masalah dapat dibedakan menjadi: 1) Strategi pemanfaatan model, alat peraga atau sketsa; 2) Strategi mencapai pola; 3) Strategi peragaan; 4) Strategi pemanfaatan tabel, daftar, gambar, bagan atau diagram alir; 5) Strategi penalaran logis dan strategi relevan lainnya. Strategi-strategi tersebut terkait dengan representasi yang nantinya akan digunakan dalam merancang sebuah pemecahan masalah. Pemilihan strategi yang tepat dapat membantu dalam merancang solusi yang diharapkan.

Memecahkan masalah matematis sangatlah sulit dan tidak ada cara magic untuk menyelesaikan semua masalah, sebab masalah merupakan sesuatu yang membutuhkan pemikiran yang lebih. Dengan kata lain, memecahkan suatu masalah maematika membutuhkan langkah-langkah yang tepat agar masalah tersebut dapat diselesaikan. Beberapa ahli menawarkan langkah-langkah pemecahan masalah di antaranya, John Dewey, Stephen Krulik dan Jesse Rudnick, Jhon D. Bransford, George Polya serta Forgaty (Sitanggang, 2016: 1516) sebagai berikut. 
Tabel 3. Langkah-langkah Penyelesaian Masalah Menurut Beberapa Ahli

\begin{tabular}{|c|c|c|c|c|c|c|c|}
\hline & Jhon Dewey & Krulik \& Rudnick & & Polya & & Bransford & Forgaty \\
\hline$>$ & $\begin{array}{l}\text { Menghadapi } \\
\text { masalah } \\
\text { Mengenal dan } \\
\text { mendefinisikan } \\
\text { masalah }\end{array}$ & $\begin{array}{l}\text { Membaca masalah } \\
>\quad \begin{array}{l}\text { Mengembangkan } \\
\text { masalah }\end{array}\end{array}$ & $>$ & $\begin{array}{l}\text { Memahami } \\
\text { masalah }\end{array}$ & $>$ & $\begin{array}{l}\text { Identifikasi } \\
\text { masalah }\end{array}$ & $\begin{array}{l}> \\
>\end{array} \begin{array}{l}\text { Menemukan } \\
\text { masalah } \\
\text { Mendefinisikan } \\
\text { masalah }\end{array}$ \\
\hline$>$ & $\begin{array}{l}\text { Menemukan } \\
\text { beberapa } \\
\text { penyelesaian }\end{array}$ & $\begin{array}{l}\text { Menentukan } \\
\text { strategi } \\
\text { penyelesaian }\end{array}$ & $>$ & $\begin{array}{l}\text { Membuat } \\
\text { rencana } \\
\text { Penyelesaian }\end{array}$ & $>$ & $\begin{array}{l}\text { Memilih } \\
\text { informasi yang } \\
\text { relevan } \\
\text { Mencari } \\
\text { alternatif } \\
\text { strategi }\end{array}$ & $\begin{array}{ll} & \begin{array}{l}\text { Mengumpulkan } \\
\text { fakta }\end{array} \\
> & \begin{array}{l}\text { Menyusun } \\
\text { hipotesis }\end{array}\end{array}$ \\
\hline$>$ & $\begin{array}{l}\text { Menduga } \\
\text { konsekuensi } \\
\text { Penyelesaian }\end{array}$ & $>\quad \begin{array}{l}\text { Menyelesaikan } \\
\text { masalah }\end{array}$ & $>$ & $\begin{array}{l}\text { Menyelesaikan } \\
\text { masalah }\end{array}$ & $>$ & $\begin{array}{l}\text { Melaksanakan } \\
\text { aternatif } \\
\text { strategi }\end{array}$ & $\begin{array}{ll}> & \text { Penelitian } \\
> & \text { Memodifikasi } \\
& \text { masalah } \\
> & \begin{array}{l}\text { Mengumpulkan } \\
\text { alternatif solusi }\end{array}\end{array}$ \\
\hline$>$ & $\begin{array}{l}\text { Menguji } \\
\text { konsekuensi } \\
\text { masalah }\end{array}$ & $\begin{array}{l}\text { Meninjau dan } \\
\text { mengembangkan } \\
\text { masalah }\end{array}$ & $>$ & $\begin{array}{l}\text { Melihat/ } \\
\text { memeriksa } \\
\text { kembali }\end{array}$ & $>$ & $\begin{array}{l}\text { Mereview dan } \\
\text { mengevaluasi } \\
\text { solusi }\end{array}$ & $\begin{array}{l}\text { Mengecek } \\
\text { kembali }\end{array}$ \\
\hline
\end{tabular}

Sumber: Adaptasi dari Sitanggang (2016, 15-16)

Menurut Polya (1973) terdapat empat langkah penting yang harus dilakukan dalam pemecahan masalah, yakni: 1) Memahami masalah; 2) Merencanakan pemecahan masalah; 3) Melaksanakan rencana; 4) Memeriksa kembali hasil yang diperoleh. Oleh karena itu, pemecahan masalah yang dimaksud dalam penelitian ini ialah serangkaian kegiatan yang dilakukan dengan menggunakan strategi tertentu dengan tujuan menemukan solusi yang tepat, dengan mengikuti langkah-langkah yang diuraikan oleh Polya, yakni 1) Memahami masalah; 2) Merencanakan pemecahan masalah; 3) Melaksanakan rencana; 4) Memeriksa kembali hasil yang diperoleh.

\section{Gaya Belajar}

Menurut Nasution (2003) gaya belajar merupakan cara siswa bereaksi dan menggunakan perangsangan yang diterimanya dalam proses belajar. Felder (1995) mengemukakan bahwa gaya belajar ialah cara seseorang dalam memperoleh, mempertahankan dan mendapatkan kembali sebuah informasi. Hasrul (2009) menyatakan, gaya belajar merupakan suatu kombinasi dari bagaimana seseorang menyerap dan kemudian mengatur serta mengolah kembali informasi tersebut. Dengan demikian, gaya belajar merupakan cara bagaimana seseorang menyerap dan mengolah informasi, belajar serta berkomunikasi sehingga menjadi sesuatu yang mudah dan indah.

Berdasarkan beberapa definisi di atas, dapat disimpulkan bahwa gaya belajar merupakan cara yang dipilih seseorang dalam memproses informasi yang diterimanya, sehingga dapat dengan mudah diolah dan diserap dalam rangka mempertahankan informasi tersebut, serta bagaimana ia mendapatkan kembali dan mengkomunikasikannya.

Terdapat berbagai macam gaya belajar, bergantung pada aspek tinjauannya. Jika ditinjau dari cara memperoleh informasi (perspectual modality), DePorter dan Hernacki (2003) membagi gaya belajar kedalam tiga kategori, yakni gaya belajar visual, auditorial dan kinestetik. Aspek ini erat kaitannya dengan representasi eksternal. Oleh karena itu, dalam penelitian ini pengkategorian gaya belajar siswa didasarkan pada aspek perspectual modality. 
a. Gaya Belajar Visual

Gaya belajar visual adalah gaya belajar yang mengandalakan kemampuan penglihatan untuk bisa memahami dan mengingatnya (Hamzah, 2005). Gaya belajar visual berarti gaya belajar yang mengandalkan pengamatan. Indera mata merupakan indera yang diutamakan dalam gaya belajar ini. Guru yang mengajar harus jeli terhadap penglihatan anak didiknya.

Beberapa karakteristik yang khas bagi orang-orang yang memiliki gaya belajar visual menurut Hamzah (2005), antara lain:

1) Kebutuhan melihat sesuatu (informasi/pelajaran) secara visual untuk mengetahui atau memahaminya;

2) Memiliki kepekaan yang kuat terhadap warna;

3) Memiliki pemamahaman yang kuat terhadap artistik;

4) Memiliki kesulitan dalam berdialog secara langsung;

5) Terlalu reaktif terhadap suara;

6) Sulit mengikuti anjuran/arahan secara lisan;

7) Sering kali salah dalam menginterpretasikan kata atau ucapan;

b. Gaya Belajar Auditori

Gaya belajar auidtori atau auditory learners adalah gaya belajar yang mengandalakan pada pendengaran untuk bisa memahami dan mengingatnya (Hamzah, 2005). Karakteristik gaya belajar auditori menempatkan pendengaran sebagai alat utama untuk menyerap dan memahami suatu informasi atau pengetahuan. Orang yang memiliki gaya belajar auditori lebih mudah menerima dan memahami pelajaran melalui suara dan kata-kata.

Beberapa karakteristik yang khas bagi orang-orang yang memiliki gaya belajar auditori menurut Hamzah (2005), antara lain:

1) Semua informasi hanya bisa diserap secara maksimal melalui pendengaran;
2) Memiliki kesulitan untuk menyerap informasi dalam bentuk tulisan secara langsung;

3) Memiliki kesulitan menulis ataupun membaca;

\section{c. Gaya Belajar Kinestetik}

Gaya belajar kinestetik biasanya disebut juga gaya belajar gerak (Suparman, 2010). Siswa dengan gaya belajar ini biasanya menyukai belajar dengan memanfaatkan anggota gerak tubuhnya dalam memahami sesuatu. Selain itu, pada umumnya mereka tidak menyukai duduk diam berlama-lama karena mempunyai keinginan untuk beraktivitas dan bereksplorasi.

Beberapa karakteristik yang khas bagi orang-orang yang memiliki gaya belajar auditori menurut Hamzah (2005), antara lain:

1) Menggunakan tangan sebagai alat penerima informasi utama agar bisa terus mengingatnya

2) Infromasi dapat diserap lebih maksimal melalui genggaman atau sentuhan

3) Tidak tahan duduk terlalu lama saat menerima pelajaran

4) Merasa bisa belajar dengan nyaman dan lebih baik apabila disertai dengan kegiatan fisik atau praktik

5) Memiliki kemampuan mengkoordinasikan sebuah tim dan kemampuan mengendalikan gerak tubuh (Atheltic ability).

\section{METODE PENELITIAN}

Penelitian ini adalah penelitian deskriptif kualitatif. Deskriptif yakni mendeskripsikan suatu keadaan atau fenomena-fenomena yang terjadi dengan apa adanya, sedangkan kualitatif didasarkan pada penelusuran representasi siswa dengan data utama berupa data kualitatif.

Subjek dalam penelitian ini adalah siswa SMP Negeri 7 Kota Jambi yang mengikuti kelas khusus pembinaan olimpiade matematika. Pemilihan subjek diawali dengan 
pemberian angket kecenderungan gaya belajar kepada calon subjek. Angket kecenderungan gaya belajar terdiri atas 30 pertanyaan yang diadaptasi dari angket yang disusun oleh Chislett \& Chapman (2005). Berdasarkan hasil angket, calon subjek dikelompokan kedalam tiga kategori gaya belajar berdasarkan aspek perspectual modality, yakni visual, auditorial dan kinestetik. Selanjutnya mereka diberikan tes pemecahan masalah matematika, berdasarkan hasil tes, dipilih satu orang siswa dari masing-masing kategori yang memiliki jawaban terbaik untuk dijadikan sebagai subjek penelitian.

\section{HASIL DAN PEMBAHASAN}

Pemilihan Subjek Penelitian

Subjek dalam penelitian ini adalah siswa

SMP Negeri 7 Kota Jambi yang mengikuti kelas khusus pembinaan olimpiade matematika yang terdiri dari 7 siswa. Pemilihan subjek diawali dengan pemberian angket kecenderungan gaya belajar kepada calon subjek. Berdasarkan hasil analisis angket diperoleh data gaya belajar masing-masing siswa. Selanjutnya mereka diberikan TPMM I. Berdasarkan hasil TPMM I, dipilih satu orang siswa dari masing-masing kategori yang memiliki jawaban terbaik untuk dijadikan sebagai subjek penelitian. Berikut pemilihan subjek berdasarkan gaya belajar dan jawaban terbaik dari TPMM I.

Tabel 4. Hasil Analisis Data terkait Gaya Belajar

\begin{tabular}{cccccc}
\hline \multirow{2}{*}{ Inisial } & \multicolumn{3}{c}{ Total Jawaban } & \multirow{2}{*}{ Jenis Gaya Belajar } & \multirow{2}{*}{ Ket } \\
\cline { 2 - 4 } & $\mathrm{A}$ & $\mathrm{B}$ & $\mathrm{C}$ & & \\
$\mathrm{AK}$ & 4 & 6 & 20 & Kinestetik & $\mathrm{S}_{3}$ \\
$\mathrm{AM}$ & 5 & 7 & 18 & Kinestetik & $\mathrm{S}_{2}$ \\
JJ & 11 & 4 & 15 & Kinestetik & \\
$\mathrm{KY}$ & 10 & 17 & 3 & Auditori & Auditori \\
KE & 10 & 12 & 8 & Visual-Kinestetik & $\mathrm{S}_{1}$ \\
NG & 12 & 6 & 12 & Visual & \\
RR & 15 & 8 & 7 & & \\
\hline
\end{tabular}

\section{Representasi Subjek Visual}

Subjek visual mampu menyelesaikan tiga masalah dengan baik dan benar. Terdapat satu masalah yang tidak dapat diselesaikan dengan baik, yaitu terkait soal kombinasi. Hal ini dikarenakan pola yang dibuat subjek tidak selesai meskipun subjek menuliskan penyelesaian masalah dengan rapi. Hal tersebut menyebabkan hasil akhir penyelesaian masalah menjadi kurang tepat. Selain itu, subjek juga mampu menyelesaikan ketiga masalah yang lain dengan langkah yang runtut dan teratur serta mampu menyelesaikan masalah dengan perencanan yang baik dan teratur. Hal ini sesuai dengan pendapat DePorter dan Hernacki (2007) yang mengungkapkan bahwa ciri individu yang memiliki gaya belajar visual adalah rapi dan terartur serta mampu membuat rencana dan pengatur jangka panjang dengan baik.

Dalam menyelesaikan empat masalah matematika yang diberikan, subjek visual cenderung membuat gambar untuk memperjelas masalah dan memfasilitasi penyelesaiannya, hal ini terlihat pada penyelesaian soal bilangan dan geometri. Dalam menyelesaikan soal permutasi dan kombinasi, subjek membuat situasi berdasarkan masalah yang diberikan. Namun, subjek juga membuat gambar berdasarkan situasi masalah yang dibuat. Hal ini menunjukkan, subjek visual meskipun menggunakan representasi kata-kata berupa situasi masalah, subjek visual juga cenderung akan membuat gambar untuk 
memperjelas masalah. berdasarkan gambar yang dibuat, subjek visual mampu menggunakan penglihatannya untuk lebih memahami masalah. Hal ini sesuai dengan pendapat Hamzah (2005) yang mengungkapkan bahwa siswa dengan gaya belajar visual mengandalakan kemampuan penglihatan untuk bisa memahami dan mengingatnya.

Selain itu, berdasarkan gambar yang dibuat, subjek visual cenderung membuat pola yang nantinya akan membantu subjek visual dalam menyelesaikan masalah yang diberikan, hal ini terlihat pada soal permutasi dan soal kombinasi. Pada soal bilangan, subjek visual juga membuat pola, namun sebelum membuat pola, subjek membuat situasi masalah untuk memahami soal yang diberikan. Berdasarkan pola tersebut subjek visual cenderung mampu Membuat kesimpulan. Hal ini terlihat pada soal bilangan permutasi, dan geometri. bahkan pada soal permutasi subjek mampu menuliskan interpretasi dari pola yang dibuat.

Subjek menunjukkan hal berbeda pada penyelesaian soal geometri. Setelah subjek membuat gambar, subjek membuat model matematika berdasarkan gambar tersebut. Dengan menggunakan model tersebut, subjek menyelesaikan masalah dengan menggunakan ekspresi matematis. Pada penyelesaian soal geometri ini, terdapat perbedaan cara penyelesaian diabandingkan dengan ketiga soal lain. Hal ini dikarenakan, pada penyelesaian soal ini, subjek hanya perlu membuat model matematika berupa rumus luas untuk menyelesaikan soal geometri.

Berdasarkan paparan di atas subjek visual cenderung mampu memenuhi ketiga indikator representasi matematis. Pada indikator representasi visual, subjek cenderung mampu membuat gambar untuk memperjelas masalah dan memfasilitasi penyelesaiannya. Pada indikator persamaan atau ekspresi matematika subjek cenderung mampu membuat pola dalam menyelesaikan masalah yang diberikan. Pada indikator kata-kata atau teks, subjek cenderung mampu membuat kesimpulan dari suatu pola.

\section{Representasi Subjek Auditori}

Subjek auditori mampu menyelesaikan tiga masalah dengan baik dan benar. Terdapat satu masalah yang tidak dapat diselesaikan dengan baik, yaitu terkait soal kombinasi. Hal ini dikarenakan subjek tidak menuliskan penyelesaian masalah tidak runtut dan teratur, sehingga terdapat pola yang tidak dibuat olehnya. Hal ini menyebabkan hasil akhir penyelesaian masalah menjadi kurang tepat. Pada penyelesaian soal kombinasi terlihat subjek mencoret jawabannya. Hal ini menunjukkan subjek tidak yakin dengan jawaban yang dibuat. Hal ini sesuai dengan penelitian Firdaus (2018) yang mengungkapkan bahwa siswa yang memiliki gaya belajar auditorial terlihat ragu-ragu dalam menuliskan penyelesaian yang telah dipikirkannya.

Dalam menyelesaikan empat masalah matematika yang diberikan, subjek auditori cenderung membuat gambar untuk memperjelas masalah dan memfasilitasi penyelesaiannya, hal ini terlihat pada penyelesaian soal bilangan dan permutasi. Dalam menyelesaikan soal kombinasi sebelum subjek membuat gambar, subjek membuat situasi berdasarkan masalah yang diberikan. Berdasarkan situasi tersebut, subjek membuat gambar untuk menyelesaikan masalah. Sedangkan pada soal geometri sebelum subjek membuat gambar, subjek membuat pola-pola geometri terlebih dahulu. Setelah membuat gambar subjek cenderung membuat pola dalam menyelesaikan masalah yang diberikan, hal ini terlihat pada penyelesaian soal bilangan dan kombinasi. Berdasarkan pola tersebut, subjek membuat kesimpulan untuk memecahkan masalah. Pada soal kombinasi, selain membuat kesimpulan berdasarkan pola, subjek juga menyelesaikan masalah dengan melibatkan ekspresi matematis.

Pada penyelesaian soal permutasi dan geometri, setelah membuat gambar subjek membuat situasi masalah berdasarkan masalah yang diberikan (soal permutasi) dan membuat model matematika dari masalah yang diberikan (soal kombinasi). Pada soal geometri, subjek juga membuat kesimpulan 


\section{$\pi$ (Phi)}

dari pola tersebut. Kemudian,subjek menyelesaikan soal permutasi dan dengan melibatkan ekspresi matematis.

Berdasarkan paparan di atas subjek auditori cenderung mampu memenuhi ketiga indikator representasi matematis. Pada indikator representasi visual, subjek cenderung mampu membuat gambar untuk memperjelas masalah dan memfasilitasi penyelesaiannya. Pada indikator persamaan atau ekspresi matematika subjek cenderung mampu membuat pola dan menyelesaikan masalah dengan melibatkan ekspresi matematis.dalam menyelesaikan masalah yang diberikan. Pada indikator kata-kata atau teks, subjek cenderung mampu membuat situasi masalah berdasarkan masalah yang diberikan dan membuat kesimpulan dari suatu pola.

\section{Representasi Subjek Kinestetik}

Subjek kinestetik hanya mampu menyelesaikan dua masalah dengan baik dan benar. Terdapat dua masalah yang tidak dapat diselesaikan dengan baik, yaitu terkait soal permutasi dan kombinasi. Hal ini dikarenakan gambar yang dibuat subjek kurang dapat ia pahami, sehingga tidak dapat membantunya dalam menyelesaikan masalah ini (soal permutasi). Penguasaan konsep yang minim mengakibatkan $\mathrm{S}_{3}$ gagal membuat pola yang tepat, sehingga ia tidak dapat menyelesaikan permasalahan tersebut dengan benar (soal kombinasi).

Dalam menyelesaikan empat masalah matematika yang diberikan, subjek kinestetik cenderung membuat gambar untuk memperjelas masalah dan memfasilitasi penyelesaiannya, hal ini terlihat pada penyelesaian keempat masalah. Dalam menyelesaikan soal bilangan dan kombinasi, subjek cenderung membuat pola yang nantinya akan membantu subjek dalam menyelesaikan masalah yang diberikan, hal ini terlihat pada soal bilangan dan soal kombinasi. Pada soal bilangan, subjek visual juga membuat pola, namun sebelum membuat pola, subjek membuat situasi masalah untuk memahami soal yang diberikan. Berdasarkan pola tersebut subjek visual cenderung mampu Membuat kesimpulan. Hal ini terlihat pada soal bilangan permutasi, dan geometri. bahkan pada soal permutasi subjek mampu menuliskan interpretasi dari pola yang dibuat. Berdasarkan pola tersebut, subjek membuat kesimpulan yang merupakan solusi dari soal bilangan. Sedangkan pada soal kombinasi, subjek mencoba membuat gambar untuk memperjelas masalah dan membantu memfasilitasi penyelesaiannya. Selanjutnya $S_{3}$ mencoba membuat pola, kemudian melibatkan ekspresi matematis dalam penyelesaiannya. Namun sayangnya, penguasaan konsep yang minim mengakibatkan $\mathrm{S}_{3}$ gagal membuat pola yang tepat, sehingga ia tidak dapat menyelesaikan permasalahan tersebut dengan benar.

Pada soal permutasi, berdasarkan gambar yang dibuat, subjek mencoba menyelesaikan masalah dengan melibatkan ekspresi matematis. Namun gambar yang dibuat subjek kurang dapat ia pahami, sehingga tidak dapat membantunya dalam menyelesaikan masalah ini. Kondisi ini diakibatkan oleh minimnya konsep-konsep yang dimiliki subjek terkait dengan permasalahan yang diberikan.

Pada soal geometri, berdasarkan gambar yang dibuat membuat gambar polapola geometri untuk memperjelas masalah dan membantu memfasilitasi penyelesaiannya. Kemudian, berdasarkan gambar tersebut subjek membuat model matematika. Dalam menyelesaikan soal geometri ini, subjek melibatkan ekspresi matematis.

Berdasarkan paparan di atas subjek kinestetik cenderung mampu memenuhi dua indikator representasi matematis, yaitu representasi visual dan representasi kata-kata atau teks tertulis. Pada indikator representasi visual, subjek cenderung mampu membuat gambar untuk memperjelas masalah dan memfasilitasi penyelesaiannya. Pada indikator kata-kata atau teks, subjek cenderung mampu membuat kesimpulan dari suatu pola. 


\section{SIMPULAN DAN SARAN \\ Kesimpulan}

Berdasarkan hasil penelitian dan pembahasan, maka diperoleh kesimpulan sebagai berikut:

1. Subjek bergaya belajar visual dan auditori, keduanya menunjukkan tiga indikator representasi matematis dalam memecahkan masalah terkait materi bilangan, permutasi, kombinasi dan geometri. Sedangkan subjek bergaya belajar kinestetik hanya menunjukkan dua indikator representasi matematis, yakni representasi visual dan representasi verbal menggunakan katakata atau teks tertulis.

2. Pada tahap penyajian data, ketiga subjek melakukannya dengan membuat gambar geometri dan model matematika berdasarkan situasi yang diberikan. Namun gambar dan model yang dibuat oleh subjek kinestetik pada soal geometri kurang tepat sehingga kurang membantu dalam menggambarkan situasi permasalahan yang sebenarnya.

3. Pada tahap penyelesaian masalah, ketiga subjek melakukannya dengan menggunakan pola dan menarik kesimpulan dari pola yang dibuat sebagai solusi penyelesaian. Selain itu subjek auditori juga menggunakan ekspresi matematika dalam penyelesaian masalah geometri.

\section{Saran}

Berikut beberapa saran dan rekomendasi terkait hasil penelitian ini:

1. Representasi matematis dan gaya belajar siswa dapat digunakan sebagai acuan dalam merancang model pembelajaran yang sesuai untuk mengembangkan kemampuan pemecahan masalah matematika siswa di sekolah.

2. Deskripsi representasi siswa dalam memecahkan masalah matematika berdasarkan gaya belajar pada penelitian ini masih terbatas pada 4 jenis soal yaitu bilangan, permutasi, kombinasi, dan geometri. Sehingga perlu penelitian lebih lanjut untuk melihat representasi siswa dalam memecahkan masalah matematika berdasarkan gaya belajar pada materi-materi lainnya.

\section{DAFTAR PUSTAKA}

Arifin. (2010). Membangun Kompetensi Pedagogis Guru Matematika. Surabaya: Lentera Cendekia.

Cai, Lane \& Jacabcsin. (1996). Assesing Student's Mathematical Comunication. School Science and Mathematics. 96(5), 238-246.

Danoebroto, S.W. (2011). Faktor-faktor yang Berpengaruh terhadap Kemampuan Siswa Memecahkan Masalah Matematika. Dipetik tanggal 15 September 2019, dari Kemendikbud P4TK Matematika pada laman https://p4tkmatematika.org/2011 110/faktor-faktor-yang-berpengaruhterhadap-kemampuan-siswamemecahkan-masalah-matematikamathematics-problem-solving/

DePorter, B. \& Hernacki, M. (2003). Quantum Learning: Membiasakan Belajar Nyaman dan Menyenangkan. Bandung: Kaifa.

Felder, R.M \& Henriques, E.R. (1995). Learning and Teaching Style in Foreign and Second Language Education. Foreign Language Annals, 28(1), 21-31.

Firdaus, H.P.E. (2018). Analisis Proses Menyelesaikan Masalah Matematika Berdasarkan Gaya Belajar Siswa Sekolah Dasar Pada Materi Operasi Perkalian Dan Pembagian Pecahan. Universitas Muhammadiyah Jember. Diunduh tanggal 25 September 2019, pada

laman http://jurnal.unmuhjember.ac.id/ index.php/JPM/article/download/421/3 14

Goldin, G.A. \& Kaput J.J. (1996). A Joint Perspective On The Idea of Representation In Learning and Doing 


\section{$\pi$ (Phi)}

Mathematics. Theories of Mathematical Learning. 397-430

Hasrul. (2009). Pemahaman Tentang Gaya Belajar. Jurnal MEDTEK, 1(2).

Hamzah B. U. (2005). Orientasi baru dalam Psikologi Pembelajaran. Jakarta: Bumi Aksara.

Hudoyo, H. (1988). Mengajar Belajar Matematika. Jakarta: Departemen Pendidikan dan Kebudayaan.

Hudoyo, H. (1997). Mengajar Belajar Matematika. Jakarta : Dirjen Dikti. Depdiknas.

Hwang, W.Y., Chen, N.S., Dung J.J. \& Yang, Y.L. (2007). Multiple Representation Skills and Creativity Effects of Mathematics Solving Using A Multimedia Whiteboard System. Educational Technology \& Society. 10(2), 191-212.

Kartini. (5 Desember 2009). Peranan Representasi dalam Pembelajaran Matematika, dipresentasikan pada Seminar nasional Matematika dan pendidikan Matematika, Jurusan Pendidikan Matematika FMIPA UNY, Yogyakarta.

Ekawati, E. (2011). Peran, Fungsi, Tujuan dan Karakteristik Matematika Sekolah. Dipetik tanggal 20 April 2020, dari Kemendikbud P4TK Matematika pada laman https://p4tkmatematika.org/2011 110/peran-fungsi-tujuan-dankarakteristik-matematika-sekolah/

Nasution, S. (2003). Berbagai Pendekatan dalam Proses Belajar Mengajar. Jakarta: Bumi Aksara.

National Counsil of Teachers of Mathematics (NCTM). (2000). Principles and Standards for School Mathematics. USA: Reston, V. A.

Polya, G. (1973). How to Solve It: A new aspect of mathematical method. New Jersey: Priceton University Press.

Sitanggang, A. D. (2017). Implementasi Pembelajaran Metode Problem Based Learning dengan Strategi Konflik Kognitif untuk Meningkatkan Kemampuan Pemecahan Masalah
Matematis dan Kemandirian Siswa ditinjau dari Gaya Belajar Siswa. Thesis (dipublikasikan online oleh Institutional Repositories \& Scientific Journals UPT Perpustakaan Universitas Pasundan). diunduh tanggal 25 April 2020 pada laman http://repository.unpas.ac.id/27016/

Suparman S. (2010). Gaya Mengajar yang Menyenangkan Siswa. Yogyakarta: Pinus. 